\title{
ASPEK REPRODUKSI IKAN WADER IJO (OSTHEOCHILUS HASSELTI) DI DANAU RAWAPENING AMBARAWA, KABUPATEN SEMARANG
}

\author{
Reproductiom Aspect of Bonylip Barb (Ostheochilus hasselti) \\ in Rawapening Lake Ambarawa, Semarang Regency \\ Muhammad Rizky Nugraha, Anhar Solichin*) dan Boedi Hendrarto \\ Program Studi Manajemen Sumberdaya Perairan, Jurusan PerIkanan \\ Fakultas PerIkanan dan Ilmu Kelautan, Universitas Diponegoro \\ J1. Prof. Soedarto, SH, Tembalang, Semarang, Jawa Tengah -50275 , Telp/Fax. +62247474698 \\ Email : mr.nugraha70@gmail.com
}

\begin{abstract}
ABSTRAK
Ikan Wader Ijo (O. hasselti) merupakan ikan khas di Danau Rawapening. Populasinya saat ini diduga mengalami penurunan, akibat penangkapan ikan Wader Ijo yang sedang bertelur dan penggunaan alat tangkap dengan mesh size kecil. Penelitian ini bertujuan untuk mengetahui aspek reproduksi ikan Wader Ijo, faktor lingkungan dan mesh size gill net yang aman digunakan. Penelitian yang dilakukan bersifat deskriptif, dengan teknik pengambilan sampel acak. Penelitian dilaksanakan Juli - Agustus 2016 di Danau Rawapening. Sampel diperoleh 93 ekor menggunakan gill net mesh size 2 inchi, dengan panjang total $111-210 \mathrm{~mm}$. Nisbah kelamin 1:6,75 dengan dominasi ikan betina. Sampel didominasi ikan matang gonad pada TKG IV. Berdasarkan analisa PCA, Ikan Wader Ijo pada TKG II, III dan IV memiliki korelasi negatif dengan $\mathrm{pH}$, arus dan oksigen terlarut. Angka Indeks Kematangan Gonad tertinggi betina diperoleh 30,30\%, sedangkan jantan 19,67\%. Ikan Wader Ijo yang tertangkap belum mengalami recruitment overfishing karena ukuran ikan pertama kali matang gonad jantan 100,63 mm dan betina 110,90 mm lebih kecil dari ukuran ratarata yang tertangkap $153 \mathrm{~mm}$. Fekunditas diperoleh 80.862 - 19.880 butir/individu. Berdasarkan analisa Regresi Power, fekunditas Wader Ijo dipengaruhi oleh panjang tubuhnya. Diameter telur yang diperoleh berkisar 0,01 - 1,01 mm. Berdasarkan analisa Chi-Square, bagian yang berbeda dalam ovarium memiliki hubungan dengan ukuran diameter telur. Mesh size gill net yang aman digunakan minimal berukuran 1,54 inchi.
\end{abstract}

Kata Kunci : Wader Ijo; Aspek Reproduksi; Rawapening

\section{ABSTRACT}

Bonylip Barb (O. hasselti) is a local fish in Rawapening lake which population of this species in Rawapening already decrease, because of exploitation spawning Bonylip Barb and the used of fishing gear with small mesh size. This research aimed to know reproduction aspects of Bonylip Barb, environmental factors and mesh size of gill net. The method used in this research was descriptive with random sampling method. A total of 93 specimens were collected by gill net mesh size 2 inch from July to August 2016 at Rawapening. Specimens have total lenght $111-210 \mathrm{~mm}$. Sex ratio was 1 : 6,75 dominated by female. Gonadal stage dominated by mature fish on level IV. Based on PCA analysis, gonadal stage level II, III and IV have negative correlations with $\mathrm{pH}$, current and dissolved oxygen. The highest Gonadosomatic Index on female was 30,30\%, while the male one was 19,67\%. Length of first maturity not only male 100,63 mm but also female 110,90 mm smaller than average length of capture $155 \mathrm{~mm}$, it means that Bonylip Barb in Rawapening still safe from recruitment overfishing. Fecundity ranged from 80.862 to 19.880 granules/individual. Based on power regression, fecundity was determined by the total length. Egg diameter ranged from 0,1 to 1,01 mm. Based on Chi-Square, different path of ovary have a corelation with egg diameter. Mesh size gill net that used in Rawapening was not recommended under 1,54 inch.

Keywords: Bonylip Barb, Reproduction Aspect, Rawapening

*) Penulis penanggungjawab

\section{PENDAHULUAN}

Menurut Dewi (2005), bahwa ikan Wader Ijo atau Nilem merupakan ikan khas di Danau Rawapening yang termasuk kedalam komoditas ikan air tawar yang memiliki nilai jual tinggi. Ikan Wader Ijo memiliki daging yang lezat dengan tekstur yang kenyal namun tidak memiiki duri yang banyak, oleh sebab itu ikan ini sangat digemari oleh masyarakat sekitar untuk dikonsumsi. Ikan Wader Ijo dikonsumsi tidak hanya sebatas pada dagingnya saja, akan tetapi telurnya juga sangat digemari oleh masyarakat sekitar. Tidak dapat dipungkiri dengan daging dan telur yang lezat, maka 
permintaan akan ikan Wader Ijo untuk dikonsumsi juga tinggi, khususnya terhadap ikan Wader Ijo yang sedang bertelur.

Seiring dengan berjalannya waktu, saat ini populasi ikan Wader Ijo (O. hasselti) di Danau Rawapening semakin menurun. Peningkatan upaya penangkapan terhadap ikan Wader Ijo yang sedang bertelur sebagai akibat tingginya permintaan masyarakat diduga menjadi salah satu penyebab dari menurunnya stok ikan Wader Ijo di Danau Rawapening. Apabila hal ini dilakukan secara terus menerus dalam jangka waktu yang lama dikhawatirkan akan terjadi recruitment overfishing. Di sisi lain penangkapan Wader Ijo dengan alat tangkap mata jaring kecil secara intensif dan menurunnya kualitas dari Danau Rawapening diduga juga menjadi penyebab menurunnya populasi Wader Ijo di Danau Rawapenng. Oleh sebab itu perlu dilakukan penelitian mengenai aspek reproduksi ikan Wader Ijo di Danau Rawapening dalam rangka pengelolaan dan pemanfaatan yang berkelanjutan.

Tujuan dari penelitian yang dilaksanakan pada Juli - Agustus 2016 adalah untuk mengetahui aspek reproduksi, ukuran mata jaring gill net yang aman digunakan dan faktor lingkungan yang mempengaruhi keberadaan ikan Wader Ijo (O. hasselti) di Danau Rawapening.

\section{MATERI DAN METODE PENELITIAN}

Materi pada penelitian ini adalah aspek reproduksi ikan Wader Ijo (O. hasselti), faktor lingkungan dan penghitungan mesh size gill net di Danau Rawapening. Aspek reproduki yang diteliti meliputi: struktur ukuran, nisbah kelamin, Tingkat Kematangan Gonad, Indeks Kematangan Gonad, fekunditas, ukuran pertama kali matang gonad dan diameter telur. Faktor lingkungan diteliti untuk mengetahui keterkaitannya dengan TKG yang meliputi: $\mathrm{pH}$, oksigen terlarut, dan kecepatan arus. Metode penelitian bersifat deskriptif. Metode pengambilan sampel dilakukan dengan random. Pengambilan sampel ikan Wader Ijo dilakukan pada dua stasiun, yaitu Kecamataan Banyubiru dan Kecamatan Tuntang. Setiap Stasiun terdiri atas tiga titik sampling. Penentuan titik sampling di setiap stasiun dilakukan satu minggu sekali berdasarkan letak posisi nelayan menjaring ikan, dengan tiap titik sampling dilakukan satu kali pengulangan. Titik sampling Kecamatan Banyubiru berada di S07018,194' E110²6,368', S070 18,070' E110²6,277'

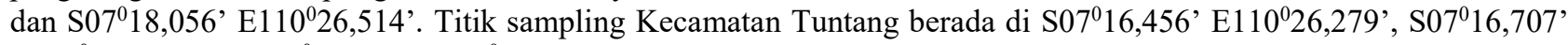
$\mathrm{E} 110^{\circ} 26,127^{\prime}$ dan $\mathrm{S} 07^{\circ} 16,572^{\prime} \mathrm{E} 110^{\circ} 26,348^{\prime}$. Penentuan jumlah sampel minimal yang dibutuhkan dihitung berdasarkan estimasi kesalahan pengukuran rata-rata panjang kurang lebih $2 \mathrm{~mm}$ pada taraf kepercayaan $95 \%$.

\section{Struktur Ukuran}

Pengukuran struktur ukuran meliputi panjang tubuh, lebar tubuh, berat tubuh, berat gonad, ukuran rata-rata yang tertangkap dan panjang infinit. Panjang dan lebar tubuh diukur menggunakan meteran dengan ketelitian $1 \mathrm{~mm}$. Berat tubuh dan gonad diukur dengan menggunakan timbangan elektrik dengan ketelitian 0,01 gram. Ukuran rata-rata yang tertangkap dihitung dengan kurva logistik baku. Panjang infinit dihitung dengan rumus:

Lo $=\frac{\text { Panjang tubuh terpanjang }}{0,95}$

Nisbah Kelamin

Nisbah kelamin dihitung dengan rumus sebagai berikut:

Nisbah kelamin $(\underline{X})=$ Jumlah Ikan jantan (ekor)

Jumlah Ikan betina (ekor)

Indeks Kematangan Gonad (IKG)

Indeks kematangan gonad dihitung menggunakan rumus rumus menurut sebagai berikut :

$$
\mathrm{IKG}=\frac{B g}{B t} \times 100 \%
$$

Keterangan :

$\mathrm{IKG}=$ Indeks Kematangan Gonad $(\%)$

$\mathrm{Bg}=$ Berat gonad (gram)

Bt = Berat tubuh (gram)

Ukuran Ikan Pertama Kali Matang Gonad (Lm)

Ukuran pertama kali matang gonad dihitung menggunakan persamaan Spearman-Karber

$$
\begin{aligned}
& m=x_{\mathrm{f}}+\frac{x}{2}-\left(x \times \sum_{i=1}^{n} P_{i}\right) \\
& \mathrm{Lm}=\operatorname{antilog} \mathrm{m}
\end{aligned}
$$

Keterangan:

$\mathrm{M}=$ Logaritma dari kelas panjang pada kematangannya yang pertama

$\mathrm{x}=$ Selisih logaritma dari pertambahan nilai tengah panjang

$\mathrm{k} \quad=$ Jumlah kelas panjang

$\mathrm{xk} \quad=$ Logaritma nilai tengah panjang dimana Ikan 100\% matang gonad (atau dimana pi $=1$ )

pi $\quad=$ Proporsi ikan matang gonad pada kelas panjang ke-i

\section{Fekunditas}

Fekunditas dihitung dengan metode Effendie(2002), dengan rumus sebagai berikut: 


$$
\mathrm{F}=\frac{G x V x X}{Q}
$$

Keterangan:

$$
\begin{array}{ll}
\mathrm{F} & =\text { Fekunditas (butir) } \\
\mathrm{G} & =\text { Berat gonad (gram) } \\
\mathrm{V} & =\text { Volume pengenceran }(\mathrm{ml}) \\
\mathrm{X} & =\text { Rata-rata jumlah telur dalam } 3 \text { kali pengulangan (butir) } \\
\mathrm{Q} & =\text { Berat gonad (telur) contoh (gram) }
\end{array}
$$

\section{Diameter Telur}

Pengamatan diameter telur ikan Wader Ijo dilakukan pada tiga bagian gonad yaitu bagian ujung gonad dekat dari lubang pengeluaran, ujung gonad jauh dari lubang pengeluaran dan tengah. Diameter telur diukur menggunakan software Motic Image Plus 2.0 yang dihubungkan dari laptop ke mikroskop digital.

\section{Penghitungan Mesh Size Gill Net}

Penghitungan mesh size gill net dilakukan dengan menggunakan rumus sebagai:

\section{Faktor Lingkungan}

$$
M S=\frac{\text { Lebar Maksimum } x \mathrm{Lm}}{\text { Panjang Maksimum }}
$$
dengan rumus:

Oksigen terlarut dihitung metode titrasi, $\mathrm{pH}$ dihitung menggunakan kertas $\mathrm{pH}$ dan kecepatan arus dihitung

$$
v=\frac{s}{t}
$$

Keterangan:

$\mathrm{v}=$ kecepatan arus $(\mathrm{m} / \mathrm{s})$

$\mathrm{s}=$ jarak yang ditempuh bola arus $(1 \mathrm{~m})$

$\mathrm{t}=$ waktu (detik)

\section{Analisa Data}

Analisis regresi power dalam penelitian ini digunakan untuk mengetahui hubungan antara panjang tubuh dengan fekunditas. Analisis Principle Component Analysis (PCA) digunakan untuk mengetahui keterkaitan antara parameter lingkungan dengan keberadaan ikan Wader Ijo pada TKG tertentu. Analisis Chi-Square digunakan untuk mengetahui keterkaitan antara bagian yang berbeda dalam ovarium dengan diameter telur. Analisa data dilakukan menggunakan software IBM SPSS Statistics 20 pada taraf tingkat kepercayaan $95 \%$.

\section{HASIL DAN PEMBAHASAN}

\section{Struktur Ukuran}

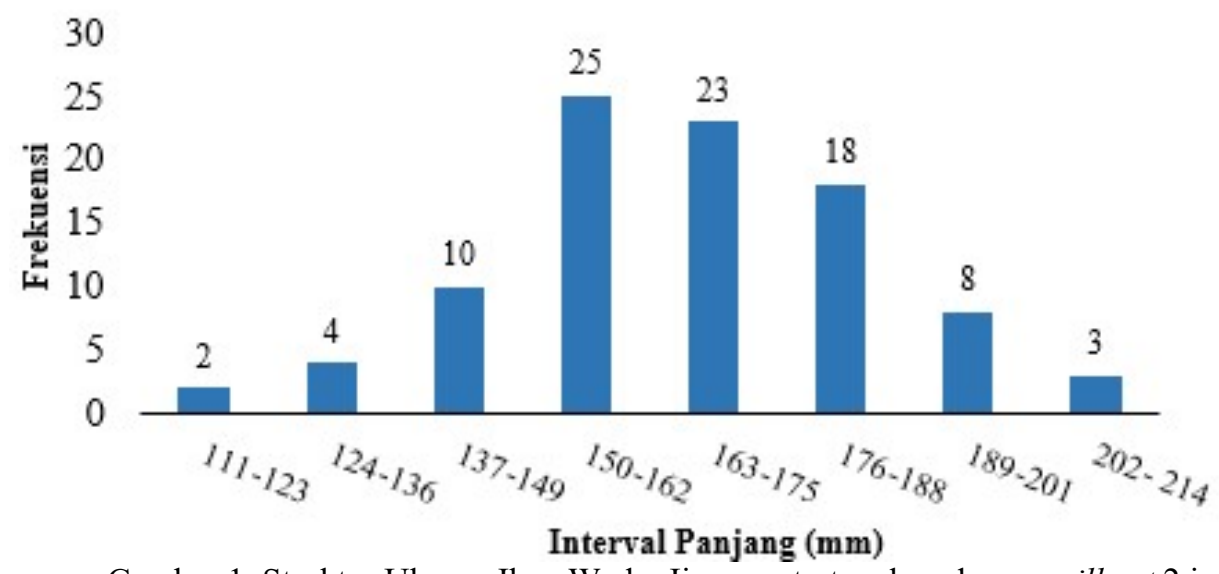

Gambar 1. Struktur Ukuran Ikan Wader Ijo yang tertangkap dengan gill net 2 inchi.

Ikan Wader Ijo yang diperoleh diperoleh dengan gill net mesh size 2 inchi selama penelitian berjumlah 93 ekor, terdiri 65 ekor dari Kecamatan Banyubiru dan 28 ekor dari Kecamatan Tuntang. Ukuran panjang minimum dan maksimum spesimen adalah $111 \mathrm{~mm}$ dan $210 \mathrm{~mm}$. Berat minimum 21,26 gram dan maksimum 144,59 gram. Ukuran rata-rata tertangkap ( $\left.\mathrm{L}_{50 \%}\right)$ ikan Wader Ijo selama penelitian adalah $153 \mathrm{~mm}$. Penghitungan mengenai panjang infinity

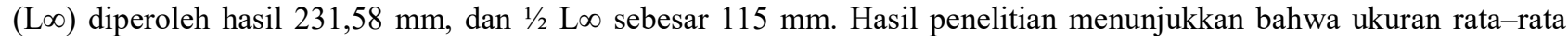
yang tertangkap lebih besar dari setengah panjang infinitnya. Menurut Saputra (2009), ukuran rata-rata ikan yang tertangkap idealnya tidak lebih kecil dari setengah panjang infinitnya. Hasil tersebut menunjukkan bahwa ikan Wader Ijo yang tertangkap belum terjadi growth overfishing. Growth overfishing terjadi jika ukuran yang tertangkap didominasi oleh ikan-ikan yang berukuran kecil, dalam hal ini adalah ikan yang didominasi dibawah ukuran rata-rata yang tertangkap. 


\section{Nisbah Kelamin}

Perbandingan rasio kelamin jantan dan betina yang diperoleh selama penelitian 1:6,75. Hasil menunjukkan adanya ketidakseimbangan antara jantan dan betina. Menurut Nababan (1994) dalam Makmur dan Prasetyo (2006), rasio jenis kelamin yang ideal di perairan adalah 1:1. Menurut Effendie (2002), perbandingan 1:1 ini sering kali menyimpang, antara lain disebabkan oleh perbedaan pola tingkah laku ikan jantan dan ikan betina, serta perbedaan laju mortalitas dari ikan. Keadaan tidak seimbangnya rasio kelamin diduga dikarenakan ikan Wader Ijo jantan dan betina yang tidak berada dalam satu area pemijahan, sehingga peluang tertangkapnya berbeda. Keseimbangan rasio kelamin dapat berubah disaat menjelang pemijahan. Menurut Nikolsky (1963), saat akan terjadi ruaya pemijahan, populasi ikan di suatu perairan didominasi oleh ikan jantan, kemudian menjelang pemijahan populasi ikan jantan dan betina berada dalam kondisi seimbang, dan kemudian didominasi oleh ikan betina. Rasio jenis kelamin dapat digunakan untuk menggambarkan kondisi populasi ikan Wader Ijo di Rawapening. Yustina dan Arnentis (2002) menyatakan, apabila jantan dan betina seimbang atau betina lebih banyak, dapat diartlkan populasi tersebut masih ideal untuk mempertahanan kelestarian. Nisbah kelamin ikan Wader Ijo di Danau Rawapening yang didominasi betina masih dapat dikatakan cukup baik.

\section{Tingkat Kematangan Gonad}

Pengamatan tingkat kematangan gonad dilakukan dengan menggunakan metode Cassie dalam Effendie (2002). Hasil pengamatan terhadap seluruh spesimen menunjukkan dominasi oleh ikan yang matang gonad sebesar $95,70 \%$, yaitu pada TKG III dan IV.

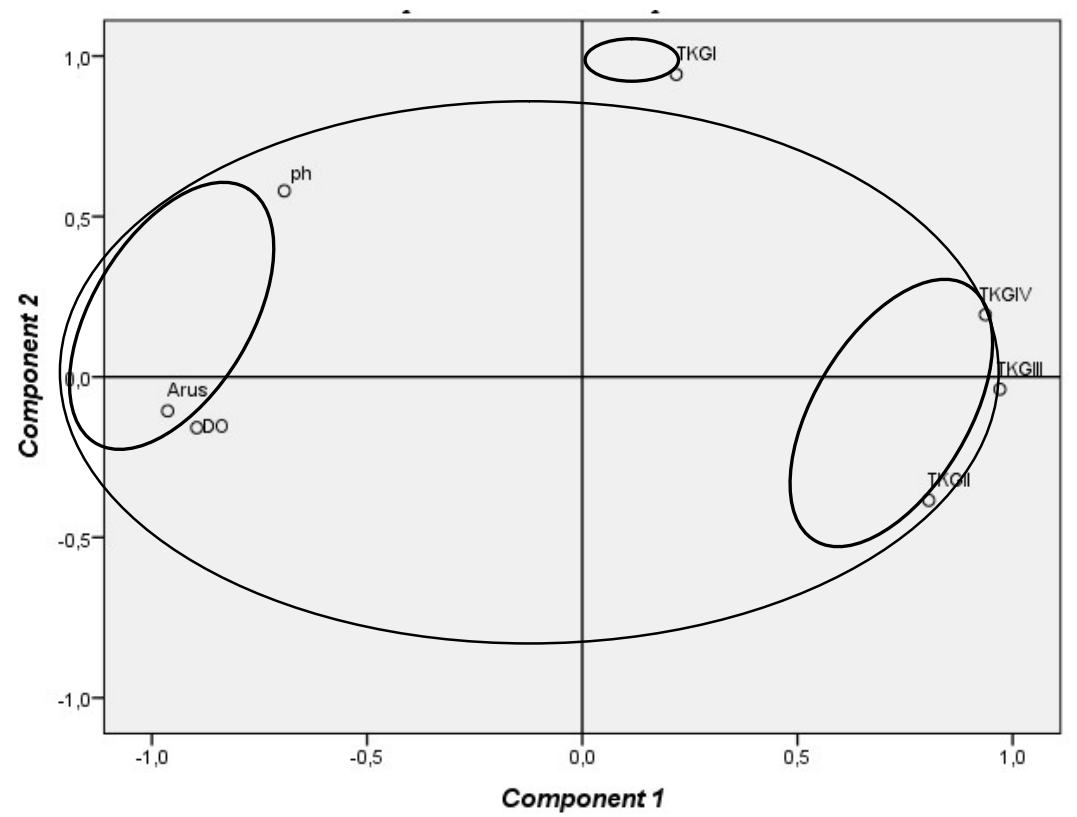

Gambar 2. Uji PCA Parameter Lingkungan dengan Tingkat Kematangan Gonad.

Berdasarkan uji analisa PCA, parameter lingkungan kecepatan arus, $\mathrm{pH}$, dan dissolved oxygen (DO) memiliki korelasi negatif dengan keberadaan ikan Wader Ijo (O. hasselti) pada TKG II, III, dan IV di Danau Rawapening. Artinya keberadaan ikan Wader Ijo pada TKG II, III dan IV semakin banyak pada kondisi pH dan oksigen telarut rendah, serta arus yang tenang. Ikan Wader Ijo pada TKG I tidak dalam satu kelompok besar, sehingga belum diketahui faktor apa saja yang mempengaruhi keberadaan dari ikan Wader Ijo (O. hasselti) TKG I di Danau Rawapening. Keberadaan ikan Wader Ijo pada TKG II, III dan IV semakin banyak pada arus yang tenang, dikarenakan ikan Wader Ijo merupakan ikan yang hidup di arus yang tenang. Menurut Ghufran (2010), O. hasselti hidup di sungai, danau, dan rawa yang memiliki arus yang sedang cenderung tenang. Keberadaan ikan Wader Ijo pada TKG II, III dan IV semakin banyak pada DO dan $\mathrm{pH}$ rendah. Hasil ini menunjukkan bagaimana Kecamatan Banyubiru yang satu hari sebelum sampling mengalami hujan diperoleh jumlah tangkapan ikan Wader Ijo yang telah matang gonad lebih banyak dari Kecamatan Tuntang. Pada saat hujan, kadar oksigen terlarut dan $\mathrm{pH}$ di suatu perairan cenderung menjadi penurunan (Effendie, 2003). Menurut fishbase.org (2016) bahwa ikan Wader Ijo melakukan migrasi dari sungai menuju daerah berkumpulnya aliran air hujan pada suatu tempat, dan kemudian kembali ke sungai lagi setelah periode musim hujan selesai.

\section{Indeks Kematangan Gonad}

Angka terbesar IKG ikan Wader Ijo betina 30,30\%, sedangkan unuk ikan Wader Ijo jantan sebesar 19,67\%. Hasil penghitungan IKG menunjukkan ikan Wader Ijo betina memiliki IKG yang lebih besar dibandingkan dengan ikan Wader Ijo jantan. Menurut Effendie (2002), bahwa indeks kematangan gonad ikan betina lebih besar dibandingkan dengan ikan jantan. Peningkatan angka IKG seiring dengan meningkatnya TKG. Hal ini dikarenakan meningkatnya TKG disertai dengan bertambah besar ukuran dan bobot dari gonad ikan, sehingga ukuran diameter telur yang ada di 
dalam gonad juga meningkat. Bobot gonad mencapai maksimum sesaat sebelum ikan akan memijah, sehingga angka IKG juga akan mencapai maksimum pada kondisi tersebut.

Angka Indeks Kematangan Gonad dapat digunakan untuk mengetahui tipe pemijahan dari ikan. Bulan Januari hingga Maret ikan Wader Ijo di Danau Rawapening didominasi ikan yang sudah matang gonad, yaitu ikan yang memiliki angka IKG tinggi (Rochmatin, 2014). Bulan Mei hingga Juli ikan Wader Ijo di Danau Rawapening didominasi ikan yang memiliki IKG tinggi (Sanjaya, 2012). Beberapa ikan dari keluarga Cyprinidae merupakan ikan dengan pola pemijahan partial spawner, yaitu ikan yang berpijah berkaitan dengan fluktuasi tingginya permukaan air akibat hujan atau banjir (Lowe-Mc Connel ,1975). Musim hujan di Indonesia terjadi di Bulan September hingga April. Umumnya ikan di daerah tropis memijah pada saat musim hujan. Hasil penelitian menunjukkan bulan Juli hingga Agustus ikan Wader Ijo didominasi ikan yang matang gonad. Berdasarkan hasil penelitian, kecenderungan pada Bulan Januari hingga Desember ikan Wader Ijo di Danau Rawapening tertangkap ikan Wader Ijo yang telah matang, sehingga dapat disimpulkan bahwa ikan Wader Ijo di Danau Rawapening mampu memijah sepanjang tahun. Menurut Ghufran (2010), bahwa ikan Wader Ijo memijah sepanjang tahun, dengan puncaknya berada di akhir musim penghujan.

Angka IKG ikan Wader Ijo yang dapat mencapai 30,30\%, menunjukkan ikan Wader Ijo memiliki gonad yang cukup besar. Besarnya gonad ikan Wader Ijo mengakibatkan ikan Wader Ijo ditangkap tidak hanya untuk dikonsumsi dagingnya, namun juga telurnya. Menurut Subagia et. al. (2006), ikan Wader Ijo saat ini dieksploitasi tidak hanya untuk dikonsumsi dagingnya saja tetapi juga telurnya, telurnya yang lezat sangat digemari masyarakat sekitar. Jika telur ikan Wader Ijo secara terus menerus dieksploitasi, dapat mengancam stok ikan Wader Ijo di Danau Rawapening, karena ikan yang siap memijah tertangkap dan tidak memiliki kesempatan untuk melahirkan keturunan. Untuk mengatasi eksploitasi telur ikan Wader Ijo di Danau Rawapening yang berlebih, dapat dicegah dengan melakukan budidaya ikan Wader Ijo menggunakan karamba jaring apung.

\section{Ukuran Pertama Kali Matang Gonad}

Ukuran ikan pertama kali matang gonad dihitung dengan menggunakan metode Sperman-Karber dengan taraf kepercayaan 95\%, diperoleh hasil ukuran ikan Wader Ijo jantan pertama kali matang gonad 100,63 mm, sedangkan pada ikan Wader Ijo betina ukuran pertama kali matang gonad adalah 110,90 mm. Berdasarkan hasil penghitungan, ikan Wader Ijo jantan lebih cepat matang gonad dibandingkan dengan ikan Wader Ijo betina. Menurut Nikolsky (1963), perbedaan ukuran ikan pertama kali matang gonad dipengaruhi oleh jenis kelamin, ketersediaan makanan, suhu, periode, cahaya dan faktor lingkungan pada suatu perairan yang berbeda-beda.

Hasil penghitungan menunjukan ukuran rata-rata ikan yang tertangkap lebih besar dari ukuran ikan Wader Ijo jantan maupun betina saat pertama kali matang gonad, sehingga ikan Wader Ijo di Danau Rawapening belum mengalami recruitment overfishing. Artinya bahwa ikan Wader Ijo mempunyai kesempatan lebih dahulu untuk memijah sebelum ditangkap. Menurut Saputra et al. (2009), bahwa ikan yang tertangkap, didominasi oleh ikan dengan ukuran yang lebih besar dari ukuran ikan pertama kali matang gonad yang artinya spesies ikan tersebut masih aman dari recruitment overfishing. Recruitment overfishing terjadi jika ikan yang tertangkap sebagian besar merupakan ikan yang belum pernah matang gonad.

\section{Fekunditas}

Penghitungan fekunditas ikan Wader Ijo diperoleh angka terendah sebesar 19.880 butir/individu, sedangkan untuk fekunditas tertinggi diperoleh 80.862 butir/individu. Berdasarkan hasil ikan Wader Ijo memiliki fekunditas yang besar. Dapat diindikasikan bahwa ikan Wader Ijo memiliki potensi reproduksi yang tinggi sehingga memiliki kemampuan daya lenting yang cukup baik, yaitu secara alami dapat kembali pulih dalam memperbaiki populasinya di alam, jika didukung pengelolaan yang baik. Menurut Habibun (2011), bahwa angka fekunditas yang tinggi memiliki arti spesies tersebut memiliki potensi reproduksi yang tinggi, sehingga berpengaruh terhadap tingginya kesedian stok dan rekruitmen spesies tersebut.

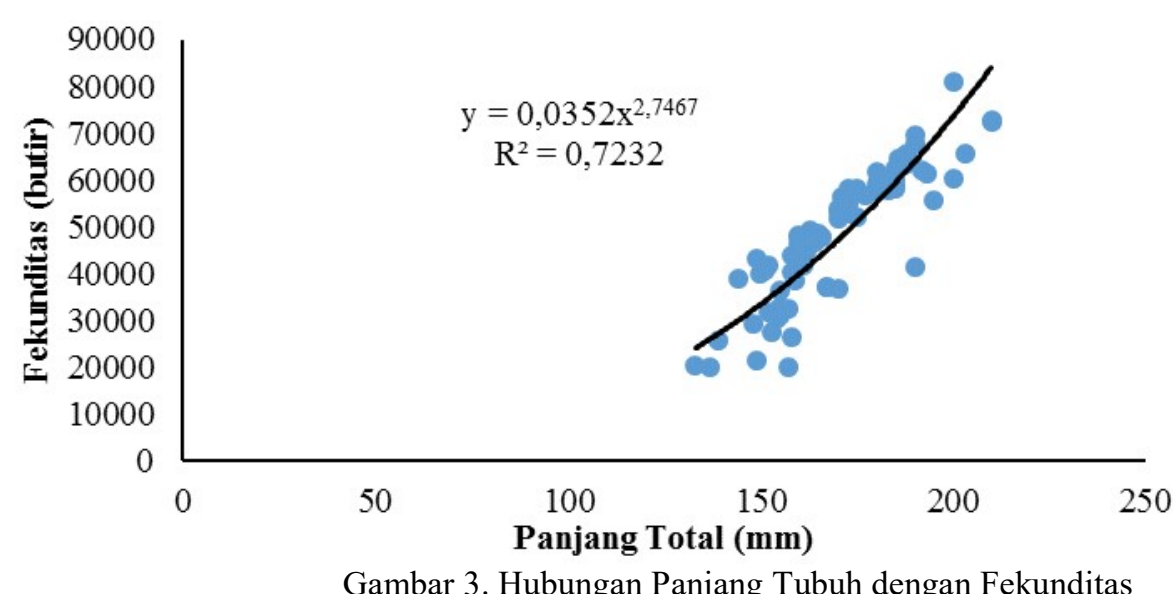

Fekunditas ikan Wader Ijo memiliki korelasi dengan panjang tubuh. Hasil analisa regresi menunjukkan angka uji signifikasi sebesar 0,00 lebih kecil dari 0,05, sedangkan koefisien determinasi diperoleh 0,706. Hasil tersebut 
menyatakan panjang tubuh mempunyai korelasi kuat terhadap fekunditas ikan Wader Ijo. Menurut Makmur (2006), bahwa fekunditas meningkat secara logaritmik terhadap panjang ikan, yang artinya semakin besar panjang maka fekunditas yang diperoleh juga semakin banyak.

\section{Diameter Telur}

Ukuran diameter telur ikan Wader Ijo berkisar 0,01 mm hingga 1,01 mm. Pengukuran diameter telur dilakukan pada ikan Wader Ijo pada TKG II, III dan IV. Pengukuran diameter telur ikan Wader Ijo pada TKG II diperoleh kisaran ukuran diameter telur 0,01 mm hingga $0,19 \mathrm{~mm}$. Hasil pengukuran diameter telur ikan Wader Ijo pada TKG III lebih besar dari TKG II, dengan kisaran ukuran diameter telur 0,07 mm hingga 0,90 mm. Kisaran ukuran diameter telur ikan Wader Ijo pada pada TKG IV merupakan yang terbesar, dengan kisaran 0,18 mm hingga 1,01 mm. Hasil pengukuran diameter telur menunjukkan terdapat peningkatan ukuran panjang diameter telur sejalan dengan peningkatan TKG. Rata-rata diameter telur ikan Wader Ijo pada tiap TKG selama penelitian tersaji pada Gambar 4.

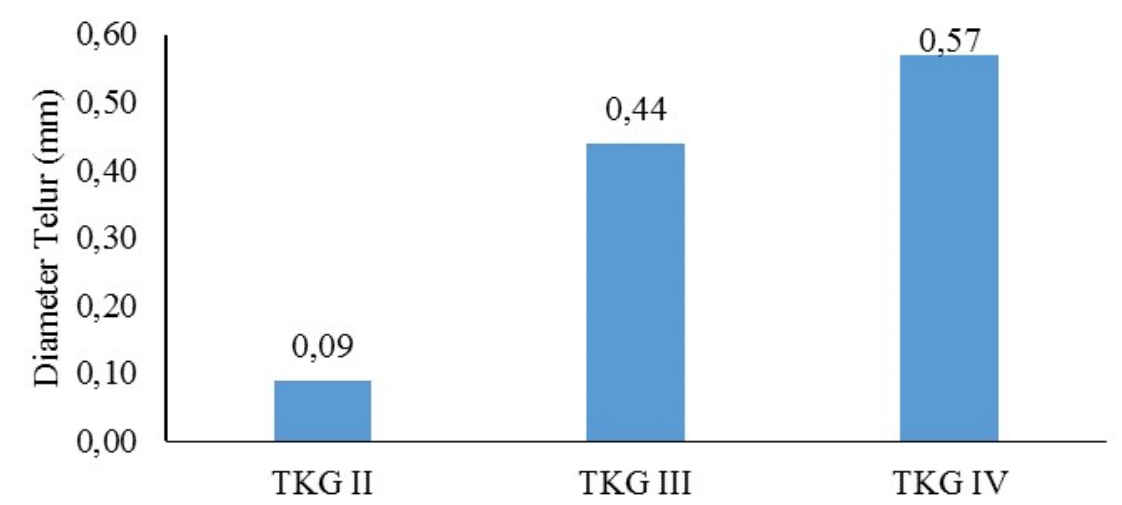

Gambar 4. Rata-Rata Diameter Telur Ikan Wader Ijo pada Tiap TKG Selama Penelitian.

Ovarium pada bagian yang berbeda dari ikan Wader Ijo yang diteliti memiliki ukuran diameter telur beragam. Distribusi, rata-rata ukuran, dan hasil Uji Chi-Square diameter telur ikan Wader Ijo pada tiap TKG di Danau Rawapening pada Bulan Juli - Agustus 2016 tersaji pada Gambar 5, Gambar 6, dan Tabel 1.

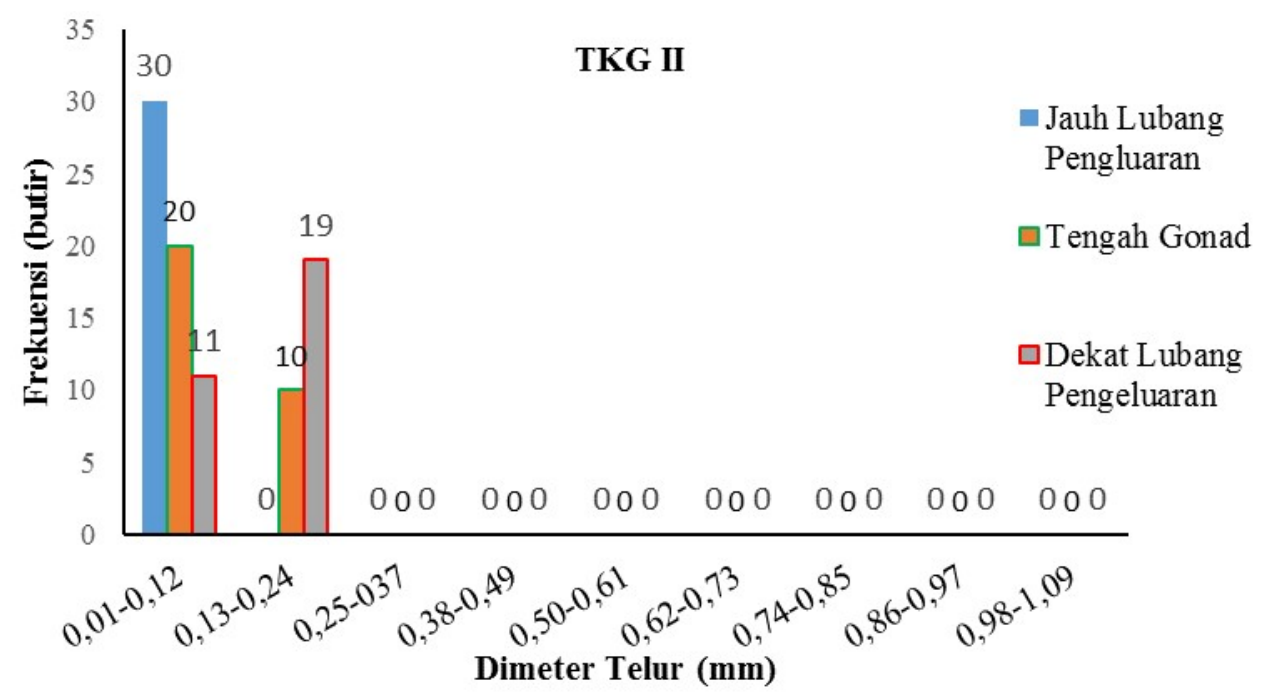

(a) 


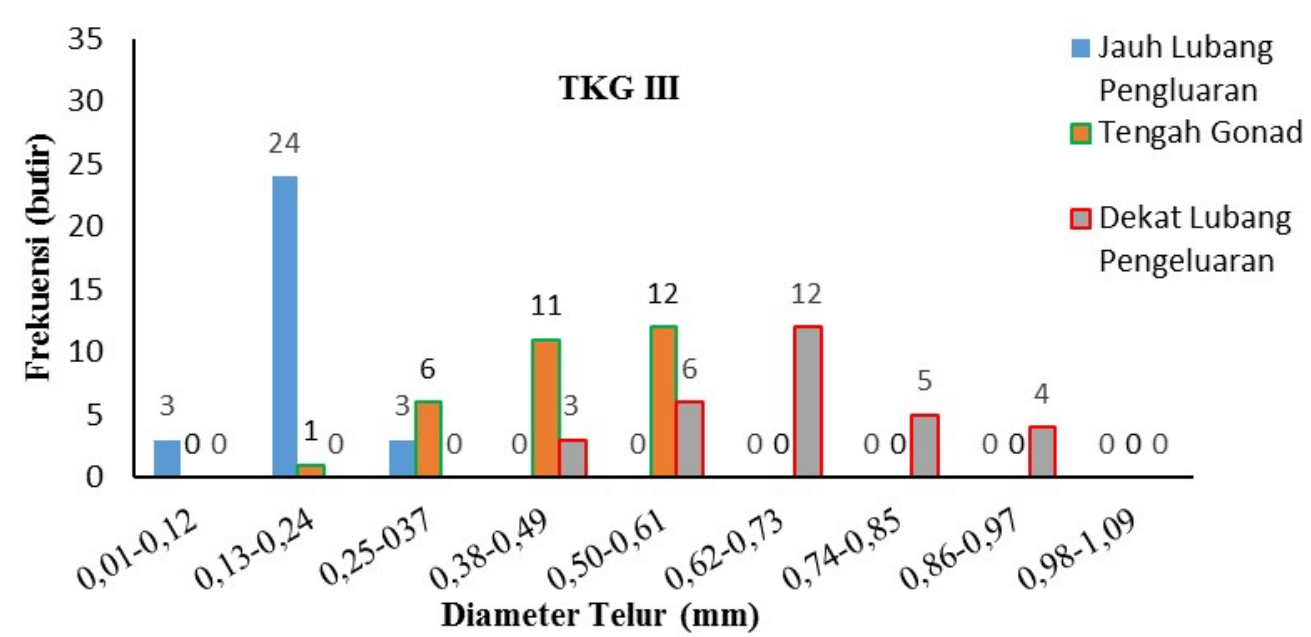

(b)

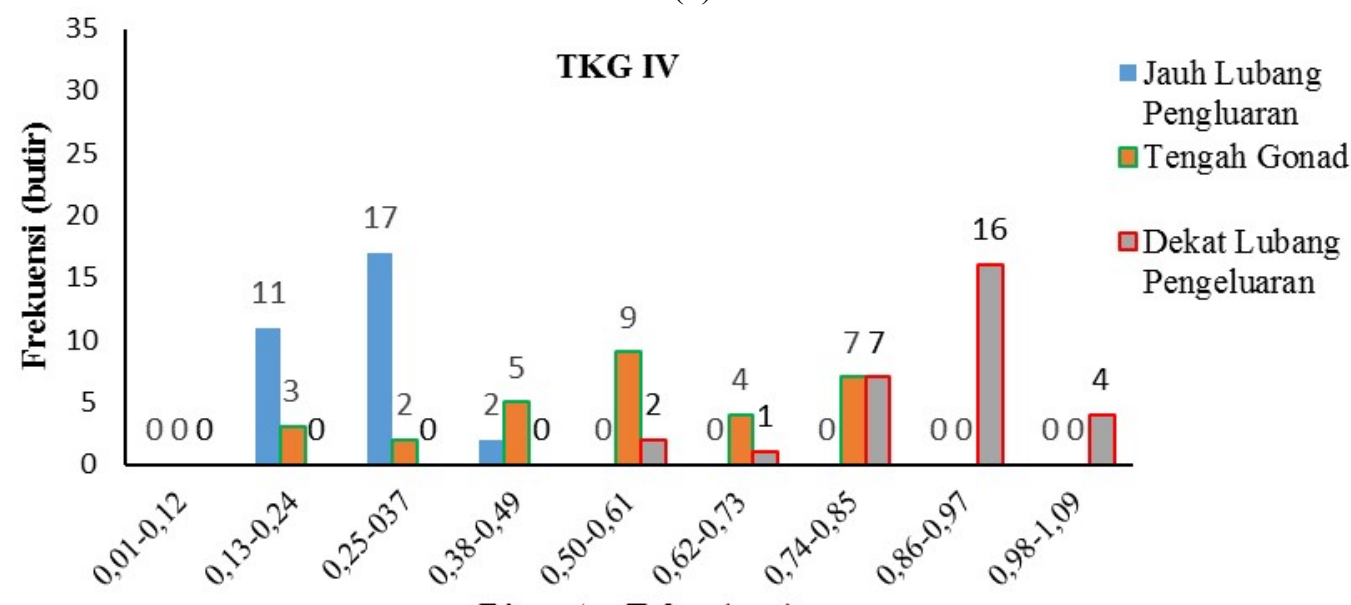

\section{Diameter Telur (mm)}

(c)

Gambar 5. Distibusi Diameter Telur Ikan Wader Ijo Tiap TKG Selama Penelitian.

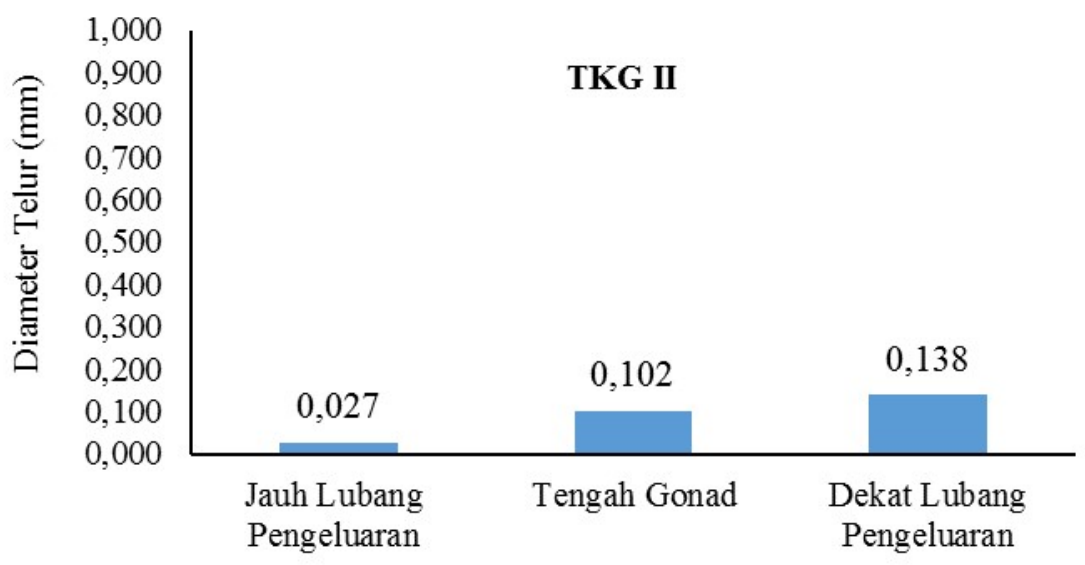

(a) 


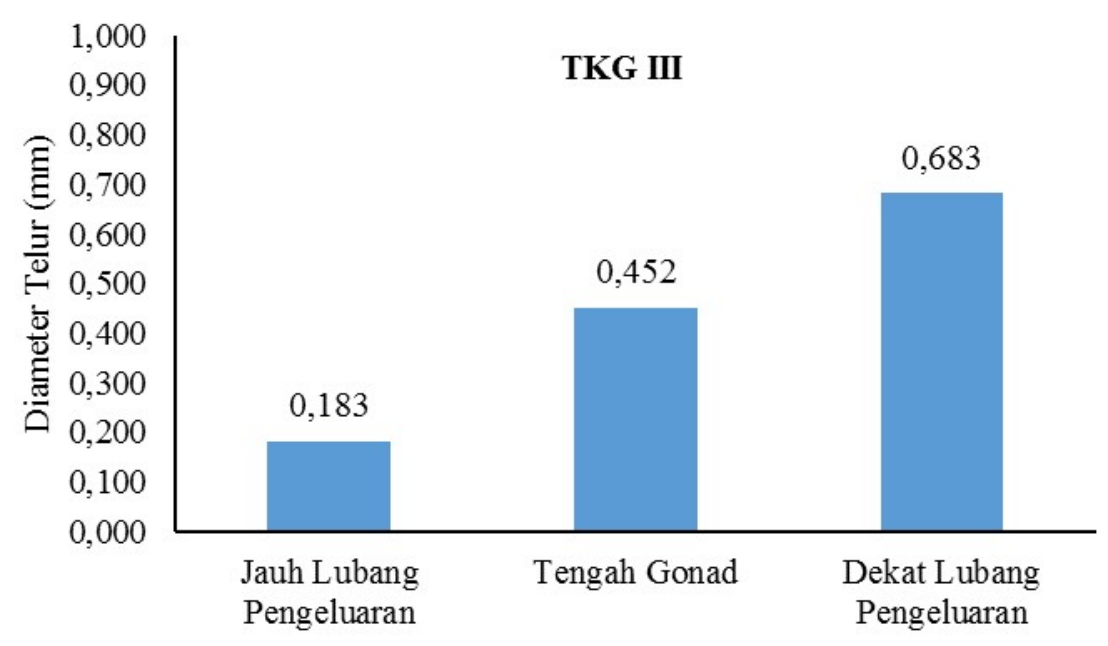

(b)

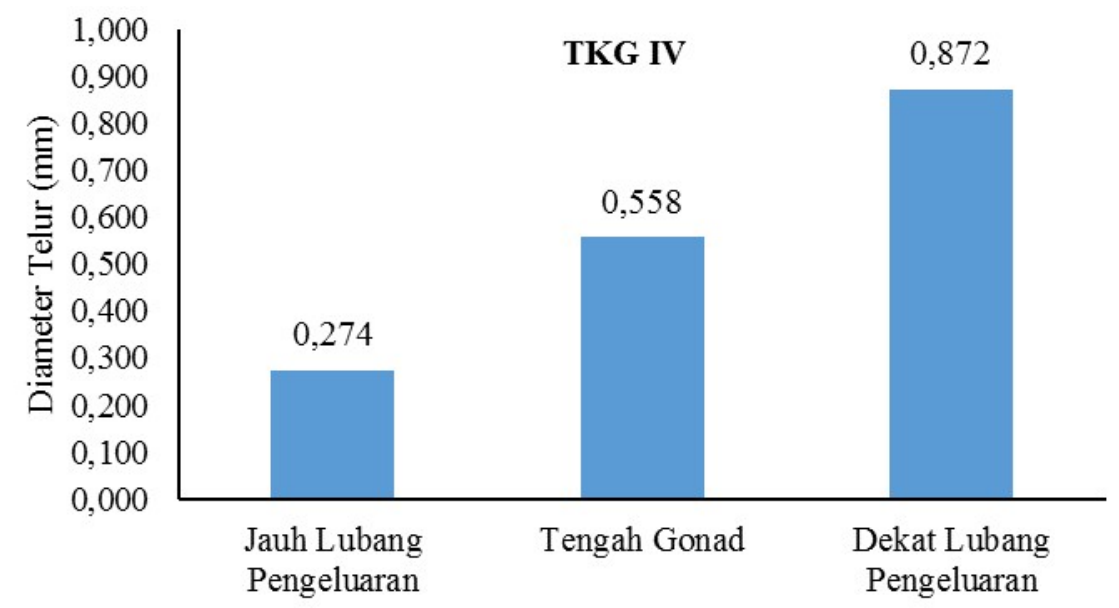

(c)

Gambar 6. Grafik Rata-Rata Ukuran Diameter Telur Ikan Wader Ijo Tiap TKG Selama Penelitian.

Tabel 1. Hasil Uji Chi-Square Letak Telur pada Gonad Terhadap Ukuran Diameter Telur Ikan Wader Ijo Selama Penelitian

\begin{tabular}{lccc}
\hline \multicolumn{1}{c}{ TKG } & $\begin{array}{c}\text { Asymp. Sig. Pearson Chi- } \\
\text { Square }\end{array}$ & $\begin{array}{c}\text { Asymp. Sig. Likelihood } \\
\text { Ratio }\end{array}$ & $\begin{array}{c}\text { Asymp. Sig. Linear-by-Linear } \\
\text { Association }\end{array}$ \\
\hline II & 0,00 & 0,00 & 0,00 \\
III & 0,00 & 0,00 & 0,00 \\
IV & 0,00 & 0,00 & 0,00 \\
\hline
\end{tabular}

Sumber: Hasil penelitian diolah menggunakan software IBM SPSS Statistics 20 pada taraf tingkat kepercayaan $95 \%$, 2016

Berdasarkan tabel diatas, letak telur pada gonad memiliki keterkaitan dengan ukuran diameter telur dalam gonad ikan Wader Ijo (O. hasselti) di Danau Rawapening. TKG II, III, dan IV diperoleh hasil angka signifikasi Pearson ChiSquare 0 lebih kecil dari 0,05. Hasil tersebut menyatakan bahwa letak telur pada gonad mempengaruhi secara nyata ukuran diameter telur yang ada di dalam gonad ikan Wader Ijo (O. hasselti).

Pola pemijahan dapat diduga dari penyebaran diameter telur ikan pada TKG IV, dengan melihat modus penyebarannya. Berdasarkan Gambar 11, pada TKG IV terlihat grafiknya memiliki dua puncak, yakni pada ukuran diameter telur $0,25-0,37 \mathrm{~mm}$ dan $0,86-0,97 \mathrm{~mm}$. Ukuran diameter telur 0,86-0,97 merupakan ukuran telur yang yang barada di dekat lubang peneluaran. Telur tersebut sudah matang dan akan dikeluarkan saat proses pemijahan. Ukuran diameter telur 0,25 - 0,37mm merupakan telur yang berada di jauh dari lubang pengeluaran, dan merupakan telur yang akan menggantlkan telur yang sudah matang dan akan dikeluarkan pada saat pemijahan. Berdasarkan hasil tersebut dapat disimpulkan ikan Wader Ijo di Danau Rawapening merupakan ikan dengan tipe masa pemijahan partial 
spawner. Hasil sama juga ditemui pada penelitian yang dilakukan oleh Harianti (2013), bahwa pada ikan pada stadia matang gonad yang akan memijah terdapat dua macam ukuran telur, yaitu telur yang berukuran kecil (masih muda) dan telur berukuran besar (sudah matang), mengindikasikan bahwa ikan tersebut mengalami kematangan dan melakukan pemijahan secara bertahap sehingga tipe pemijahannya bersifat partial spawner. Menurut Effendie (2002), partial spawner merupakan pemijahan sebagian demi sebagian yang dapat berlangsung beberapa hari, ikan betina biasanya tetap tinggal di daerah pemijahan selama proses pemijahan belum selesai, apabila sudah selesai ikan jantan yang tinggal lebih lama pada daerah tersebut. Menurut Lowe-Mc Connel (1975), bahwa beberapa ikan dari keluarga Cyprinidae merupakan ikan dengan pola pemijahan partial spawner, yaitu ikan yang berpijah berkaitan dengan fluktuasi tingginya permukaan air akibat hujan atau banjir.

Lama pemijahan pada ikan dapat diduga dari frekuensi ukuran dameter telur. Berdasarkan Gambar 4 dan 5, serta hasil Uji Chi-Square diperoleh hasil bahwa bagian yang berbeda dalam ovarium yang telah matang gonad memiliki hubungan dengan diameter telur. Berdasarkan analisa tersebut dapat diartikan bahwa bagian dalam ovarium memiliki telur dengan diameter yang berbeda-beda, sehingga dapat diindikasikan ikan Wader Ijo di Danau Rawapening memiliki waktu pemijahan yang panjang. Menurut Effendie (2002), bahwa ovarium yang mengandung telur masak berukuran sama semua menunjukkan waktu pemijahannya pendek, sebaliknya waktu pemijahan yang panjang dan terus menerus ditandai dengan banyaknya ukuran telur yang berbeda di dalam ovarium.

\section{Mesh Size Gill Net}

Hasil perhitungan terhadap mesh size gill net yang aman digunakan adalah 1,54 inchi. Berdasarkan sampling lapangan, nelayan ikan Wader Ijo baik di Tutang maupun Banyubiru menggunakan gill net ukuran mata jaring 1,75 inchi, 2 inchi dan 2,25 inchi. Dengan ukuran gill net nelayan yang lebih besar dari ukuran yang direkomendasIkan, penangkapan ikan Wader Ijo masih dikatakan aman. Hal yang perlu dilakukan dalam pengelolaan sumberdaya ikan Wader Ijo adalah dengan menjaga ukuran jaring yang digunakan, sehingga ukuran jaring yang digunakan tidak lebih kecil dari 1,54 inchi. Penggunaan mata jaring diatas 1,54 inchi dapat memberikan kesempatan pada ikan Wader Ijo untuk tumbuh dan melakukan reproduksi.

Penggunaan gill net di Danau Rawapening diatur dalam Peraturan Daerah Kabupaten Semarang No. 25 tahun 2001, yang menyatakan bahwa penggunaan gill net minimal dengan ukuran mata jaring dua inchi. Namun pada kenyataannya nelayan masih ada yang menggunakan mata jaring dibawah dua inchi. Oleh karena itu diperlukan fungsi kontrol dari pemerintah untuk tetap menjaga agar ukuran jaring yang digunakan tidak kurang dari dua inchi.

\section{KESIMPULAN}

Ikan Wader Ijo merupakan ikan yang memiliki potensi reproduksi yang besar. Hal ini dikarenakan ikan Wader Ijo memiliki ukuran gonad yang cukup besar dan memiliki jumlah telur yang banyak dalam ovariumnya. Berdasarkan analisa terhadap diameter telur, ikan Wader Ijo tergolong ikan yang memijah secara partial spawner dan mampu memijah sepanjang tahun. Kondisi ikan Wader Ijo yang tertangkap dengan gill net mesh size 2 inchi di Danau Rawapening pada Bulan Juli - Agustus 2016 didominasi ikan yang telah matang gonad namun memiliki perbandingan jumlah jantan dan betina yang tidak seimbang. Keberadaan ikan Wader Ijo di Danau Rawapening memiliki korelasi negatif terhadap oksigen terlarut, $\mathrm{pH}$ dan kecepatan arus. Mesh size gill net 2 inchi yang digunakan oleh nelayan sekitar masih aman untuk digunakan karena keberadaan ikan Wader Ijo yang tertangkap di Danau Rawapening belum mengalami growth overfishing dan recruitment overfishing.

\section{UCAPAN TERIMAKASIH}

Ucapan terimakasih ditujukan kepada Dr. Ir. Bambang Sulardiono, M.Si., Dra. Niniek Widyorini, MS., Churun Ain, S.Pi., M.Si., Dr. Ir. Pujiono Wahyu P., MS., yang telah memberikan masukan, kritik dan saran yang sangat berarti bagi penulis.

\section{DAFTAR PUSTAKA}

Dewi K. dan Soeminto. 2005. Pertumbuhan Ikan Nilem (Osteochilus hasselti) Ginogenesis sampai Umur 30 Hari Serta Tingkat Perkembangan Gonad yang Telah Dicapai. Jurnal Ikhtiologi Indonesia., 5(2): 55-59.

Effendie, M. I. 2002. Biologi PerIkanan. Yayasan Pustaka Nusatama. Yogyakarta.

Effendi, H. 2003. Telaah Kualitas Air bagi Pengelolaan Sumber Daya dan Lingkungan Perairan. Kanisius, Yogyakarta.

Ghufron, M. dan H. Kordi. 2010. Buku Pintar Pemeliharaan 14 Ikan Air Tawar Ekonomis di Keramba Jaring Apung. Lily Publisher. Yogyakarta.

Harianti. 2013. Fekunditas dan Diameter Telur Ikan Gabus (Channa Striata Bloch, 1793) di Danau Tempe, Kabupaten Wajo. Jurnal Saintek Perikanan., 8(2):18 - 24. 
Habibun, E. K. 2011. Aspek Pertumbuhan dan Reproduksi Ikan Ekor Kuning (Caesio cuning) yang Didaratkan di Pangkalan Pendaratan Ikan Pulau Pramuka, Kepulauan Seribu, Jakarta. [Skripsi]. Program Sarjana, Institut Pertanian Bogor. Bogor.

Luna, S. M. 2016. Ostheochilus vittatus (Valenciennes, 1842). Fishbase.org/summary/Osteochilus-vittatus.html(30 November 2016).

Makmur, S., dan D. Prasetyo. 2006. Kebiasaan Makan, Tingkat Kematangan Gonad, dan Fekunditas Ikan Haruan (Channa striata Bloch), di Suaka PerIkanan Sungai Sambujur, DAS Barito, Kalimantan Selatan. Jurnal IlmuIlmu Perikanan dan Kelautan Indonesia., 13(1):27 - 31.

Nikolsky, G.V. 1963. The Ecology of fishes. Academic Press. New York.

Rochmatin, S. T., A. Solichin, dan S. W. Saputra. 2014. Aspek Pertumbuhan dan Reproduksi Ikan Nilem (Osteochilus hasselti) di Perairan Rawa Pening Kecamatan Tuntang Kabupaten Semarang. Diponegoro Journal Of Maquares., 3(3): 153 - 159.

Sanjaya, N. A,. 2012. Aspek Reproduksi Ikan Nilem (Osteochilus hasselti) di Perairan Rawa Pening Kabupaten Semarang. [Skripsi]. Fakultas Perikanan dan Ilmu Kelautan. Universitas Diponegoro. Semarang.

Saputra, W.S., P. Soedarsono dan G.A. Sulistyawati. 2009. Beberapa Aspek Biologi Ikan Kuniran (Upeneus sp) di Perairan Demak. Jurnal Saintek Perikanan., 5(1): 1-6.

Subagja, J., R. Gustiano dan L. Winarlin. 2006. Pelestarian Ikan Nilem (Osteochilus hasselti C.V) melalui Teknologi Pembenihannya. Laporan Hasil Riset Balai Riset PerIkanan Budidaya Air Tawar. Bogor, Badan Riset Perikanan dan Kelautan Hlm. 279 - 286.

Widodo, J. dan Suadi. 2006. Pengelolaan Sumberdaya PerIkanan Laut. Gajah Mada University Press. Yogyakarta.

Yustina dan Arnentis. 2002. Aspek Reproduksi Ikan Kapiek (Puntius schwanefeldi Bleeker) di Sungai Rangau-Riau, Sumatera. Jurnal Matematika dan Sains., 7:5 - 14. 